\title{
A national landslide inventory of Denmark
}

Gregor Luetzenburg ${ }^{1}$, Kristian Svennevig ${ }^{2}$, Anders A. Bjørk ${ }^{1}$, Marie Keiding ${ }^{2}$, Aart Kroon ${ }^{1}$

${ }^{1}$ Department of Geosciences and Natural Resource Management, University of Copenhagen, Copenhagen, Denmark

${ }^{2}$ Geological Survey of Denmark and Greenland (GEUS), Copenhagen, Denmark

5 Correspondence to: Gregor Luetzenburg (gl@ign.ku.dk) and Kristian Svennevig (sv@geus.dk) 


\section{Abstract.}

Landslides are a frequent natural hazard occurring globally in regions with steep topography. Additionally, landslides are

10 playing an important role in landscape evolution by transporting sediment downslope. Landslide inventory mapping is a common technique to assess the spatial distribution and extend of landslides in an area of interest. High-resolution digital elevation models (DEMs) have proven to be useful databases to map landslides in large areas across different land covers and topography. So far, Denmark had no national landslide inventory. Here we create the first comprehensive national landslide inventory for Denmark derived from a $40 \mathrm{~cm}$ resolution DEM from 2015 supported by several $12.5 \mathrm{~cm}$ resolution orthophotos.

15 The landslide inventory is created based on a manual expert-based mapping approach, and we implemented a quality control mechanism to assess the completeness of the inventory. Overall, we mapped 3202 landslide polygons in Denmark with a level of completeness of $87 \%$. The landslide inventory can act as a starting point for a more comprehensive hazard and risk reduction framework for Denmark. Furthermore, machine-learning algorithms can use the dataset as a training dataset to improve future automated mapping approaches. The complete landslide inventory is made freely available for download at

https://doi.org/10.6084/m9.figshare.16965439.v1 (Svennevig and Luetzenburg, 2021) or as web map
(https://data.geus.dk/landskred/) for further investigations. 


\section{Introduction}

Landslides can be a serious natural hazard, existing worldwide causing high numbers of fatalities and damage to property every year (Froude and Petley, 2018). Identifying areas with frequent occurrences of landslides and designating areas with high landslide probabilities is important to protect human life and economic interest (Colombo et al., 2005; Ludwig et al., 2018). Furthermore, landslides play an important role in the evolution of landscapes by mobilizing and transporting sediment downslope (Moon et al., 2015). Under the generic term 'landslide' a variety of types can be distinguished based on the process and the material involved (Cruden and Varnes, 1996). Several landslide classifications exist that have been refined over the years (Highland and Bobrowsky, 2008; Hungr et al., 2014). When investigating a landslide, gaining knowledge about the

30 spatial occurrence of landslides can further improve our understanding of the underlying processes causing landslides (Malamud et al., 2004).

The study of landslides reaches from site-specific field investigations to global datasets of landslides and from event-based inspections to long-term monitoring for several years (Alberti et al., 2020; Coe, 2020; Mateos et al., 2020; Svennevig et al., 2020b). Among the different spatial and temporal approaches of landslide studies, landslide inventory mapping is a common method to investigate the spatial occurrence of landslides (Guzzetti et al., 2012; Galli et al., 2008; Hao et al., 2020). Landslide inventory mapping can be performed remotely, covering large areas, with the option to validate the dataset in the field (Zieher et al., 2016). Traditionally landslide inventories are based on aerial imagery and optical satellite images (Brardinoni et al., 2003; Fiorucci et al., 2011). With the emergence of digital elevation data, the quality and quantity of landslide inventories have improved substantially (Morgan et al., 2011; Kakavas and Nikolakopoulos, 2021). New areas can be investigated (e.g. forests) and volumes of displaced mass can be calculated (Cavalli and Marchi, 2008). Landslide inventories often contain information about the landslide location, geometry, date of occurrence and damage caused by the landslide (Rosi et al., 2017; Palma et al., 2020).

45 National elevation mapping efforts and satellite campaigns are extending the areas that are covered by elevation models (Crosby, 2012; Eea, 2016). Advances in sensor technologies and satellite orbit repeat rates are improving the spatial and temporal resolution of the available data, both for optical images and elevation data (e.g. Shugar et al., 2021). Remote sensing data provides powerful information for landslide mapping, but a combination of different datasets such as digital elevation models (DEM's) and multispectral satellite images is necessary to overcome the limitations of each individual dataset (Lissak

50 et al., 2020). The quality of manually mapped landslide inventories strongly depends on the mapping expert's knowledge about the area of investigation (Van Den Eeckhaut et al., 2005). With the emergence of machine and deep learning techniques, landslide inventory mapping is often at least partly performed by computers that identify landslides based on a predefined set of parameters (e.g. slope angle, surface roughness) (Chang et al., 2019). The combination of machine learning algorithms and remote sensing data is expected to greatly improve the quality of landslide mapping datasets (Zhong et al., 2020). However, field validation of these newly created data sets is essential. Semi-automated mapping approaches can reduce the subjectivity introduced by visual landform interpretation (Santangelo et al., 2015). Besides, machine and deep learning algorithms require training data. The limited availability of training datasets and the complexity of automated landslide mapping methods lead to still mostly human efforts in creating landslide inventories (Prakash et al., 2020). Evaluating the quality of landslide inventories is not straightforward and most mapping efforts do not implement quality controls into their inventory (Guzzetti et al., 2012; Pellicani and Spilotro, 2014; Hao et al., 2020).

Landslide inventories exist on regional, national, international, and global scale (Kirschbaum et al., 2009; Trigila et al., 2010; Damm and Klose, 2015; Herrera et al., 2017). Within Europe, Denmark does not have a national landslide inventory, nor a 
legislation framework to incorporate landslides and landslide related damages into national law (Mateos et al., 2020).

Landslides are considered a predominant natural hazard in the Nordic countries (Nadim et al., 2008) and a number of case studies investigated landslides in Denmark (Hutchinson, 2002; Prior, 1977). Pedersen et al.(1989) states that Denmark is not a country with a serious landslide problem. However, a recent paper raised concern that the geo-hazard posed by landslides in Denmark is underestimated (Svennevig et al., 2020a).

Previous work suggests that some coastal mudflows and rotational landslides in Denmark are triggered by water infiltration into the soil and underlying Quaternary deposits, activating the shear plane (Prior and Eve, 1975). Water can infiltrate the potential surface of rupture from precipitation events and impermeable clay layers may act as sliding surfaces. Besides, the waves in the coastal areas may remove the toe of landslides and trigger further slope instabilities. Limited records exist of landslides triggered by earthquakes in Sweden, but no records are available for Denmark (Mäntyniemi et al., 2020). Previous studies have described rockfalls, rotational slides, mudslides, and mudflows, mostly in coastal cliffs in Denmark (Prior, 1977; Pedersen et al., 1989; Busby et al., 2002; Svennevig and Keiding, 2020). With this paper and dataset, we present the first comprehensive landslide inventory for Denmark.

\section{Study area}

Denmark consists of the Jutland peninsula and an archipelago of 394 islands encompassing $43,938 \mathrm{~km}^{2}$ in total with $8,750 \mathrm{~km}$ of coastline (Fig. 1). The landscape is characterized by a low relief with the highest point $171 \mathrm{~m}$ above sea level in central Jutland. A long history of agricultural land use has shaped the landscape. Today, around $61 \%$ of the area is agriculturally used, $13 \%$ are forests, another $13 \%$ are transport routes and build up areas, and the remaining land is covered with open habitats and water bodies (Denmark, 2019).

Today's Danish landscape was shaped by numerous glaciations, dominated almost entirely by the two latest, the Saalian, ending c. $130 \mathrm{ka} \mathrm{BP}$ and the most recent Weichselian ending c. $16 \mathrm{ka} \mathrm{BP}$, which lead into the Holocene (Houmark-Nielsen, 1999; Houmark-Nielsen, 2011). The current landscape configuration is primarily dominated by the last glacial maximum (LGM) extent reached during the Weichselian at c. $22 \mathrm{ka} \mathrm{BP,} \mathrm{where} \mathrm{a} \mathrm{glacial} \mathrm{advance} \mathrm{from} \mathrm{the} \mathrm{Northeast} \mathrm{reached} \mathrm{mid-Jutland,}$ leaving two distinct surface sedimentation regimes: (1) the ice-free west was dominated by sandy glacio-fluvial outwash plains surrounding older glacial deposits from the Saalian; (2) the ice overridden eastern part of Denmark was dominated by glacial processes depositing tills with a high clay content. The landscape here was mainly shaped during the LGM advance and the numerous re-advances up until c. 16 ka BP (Houmark-Nielsen, 1999; Houmark-Nielsen, 2011). Postglacial isostatic rebound has affected especially the northern part of Denmark, which has been uplifted by up to $13 \mathrm{~m}$ relative to the local sea-level, exposing raised beaches and marine terraces.

95

The Quaternary deposits in Denmark typically comprise tens of meters of glacial diamicton and outwash deposits, but in some places, the Quaternary layer is thinner. Generally, the distribution of Pre-Quaternary deposits follows a pattern from older to younger from the northeast to the southwest (Sorgenfrei and Berthelsen, 1954). The oldest Pre-Quaternary deposits are found on the island of Bornholm to the southeast where a Precambrian crystalline basement and Palaeozoic and Mesozoic sediments are exposed. In northernmost Jutland, Lower Cretaceous sediments are found below thick Quaternary deposits. Sediments are progressively younger to the southwest and in southern Jutland Miocene and Pliocene clastic sediments are found. Of particular relevance to landslide occurrence are Paleogene plastic clays (Prior, 1977). These are present in a belt from the Limfjorden area in the northwest through eastern Jutland and northwest Zealand and are in many places found inter-thrusted with glaciogenic deposits in glaciotectonic complexes. Cretaceous and Danian limestone cliffs are found locally in a belt northeast 

occur (Busby et al., 2002; Hutchinson, 2002; Pedersen and Møller, 2004; Pedersen and Gravesen, 2009; Pedersen and Damholt, 2012).

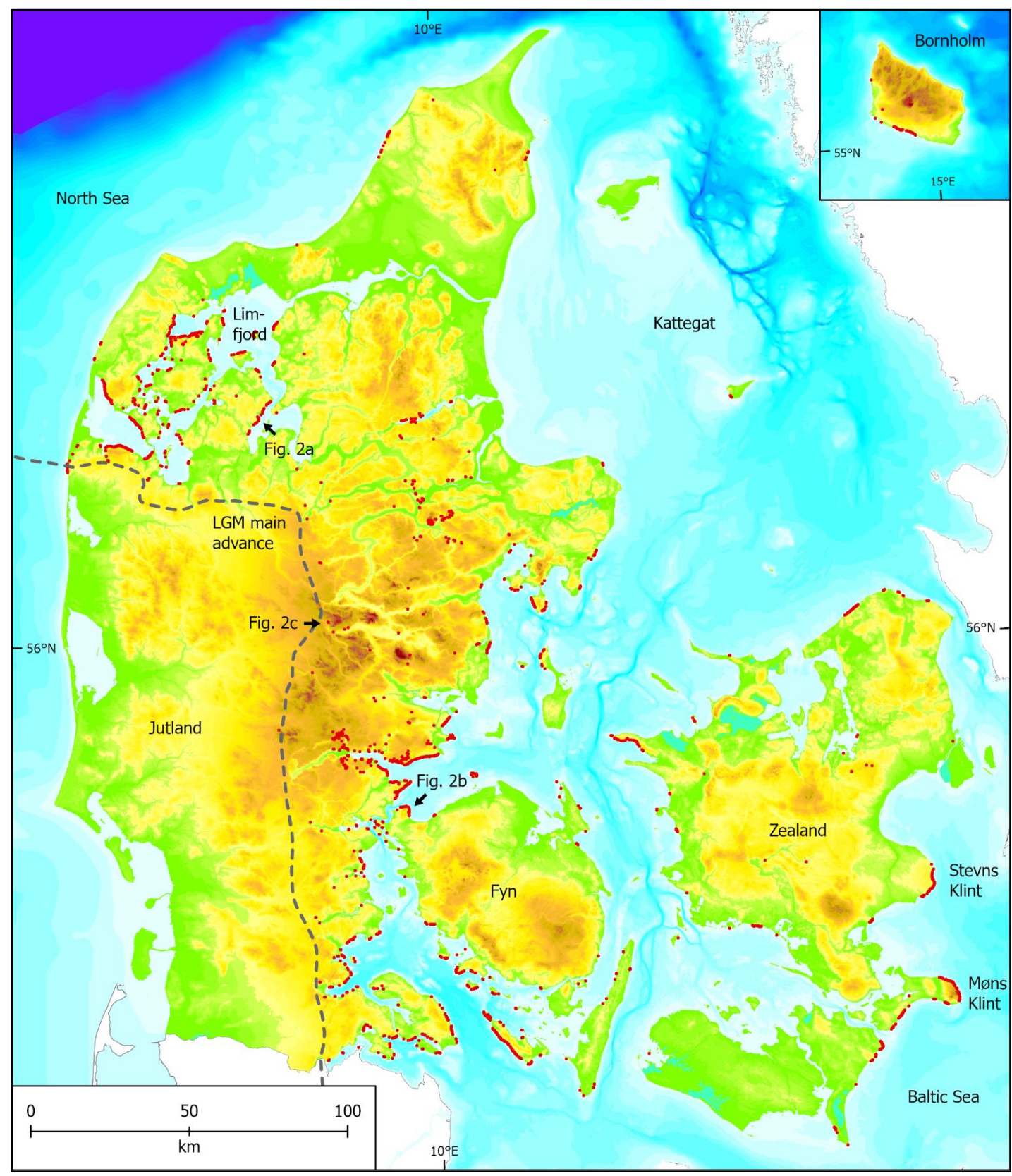

Figure 1. Landslide inventory of Denmark. Red dots show 3202 mapped landslides. Dashed line indicates the maximum advance of the ice sheet during the Weichsel glaciation (Houmark-Nielsen, 2011). Place names mentioned in the text along with positions of panels in Fig. 2 are shown. 
Open waters occur in many places in Denmark (Fig. 1) and the glacial landscape is often eroded along its fringes by coastal processes. Waves induce large swash run up on the beaches and cause erosion of the glacial landscape forming coastal cliffs. These relatively steep cliffs are susceptible to landslides, if the conditioning geology is present. The landslides in the coastal cliffs are presumably sensitive to a combination of water infiltration and specific run-off patterns over impermeable layers in the substrate, and to wave erosion of the cliff toe by swash run up during high water levels under storm conditions (Schou, 1949). The eroded sediment of the coastal cliffs and specifically the landslides in the cliffs, are further transported towards deeper water in a cross-shore direction or along the shores by wave-driven longshore currents forming accreted forms like barrier islands and spits (Kabuth et al., 2013; Kabuth and Kroon, 2014).

\section{Methodology}

\subsection{Data sources}

The main datasets used in this study are a high-resolution DEM from 2015 and orthophotos provided by the Danish Agency for Data Supply and Efficiency (SDFE). The national DEM is produced from airborne LiDAR scans with a spatial resolution of $40 \mathrm{~cm}$ and is freely available (Geodatastyrelsen, 2015b). Several multi-temporal nationwide orthophotos with a resolution of $12.5 \mathrm{~cm}$ complement the mapping effort for visual validation of landslide features in the landscape (Geodatastyrelsen, 2015a). Table 1 shows a complete list of the datasets used to map landslides in this study.

130 Table 1. Freely available data from the Danish Agency for Data Supply and Efficiency (SDFE) used in the landslide mapping. See Data availability section for links to the datasets. Adapted from Svennevig et al. (2020a).

\begin{tabular}{lllll}
\hline Name & Type & Year & Source & Resolution (cm) \\
\hline Geodanmark 2020 & Orthophoto & 2020 & SDFE & 12.5 \\
\hline Geodanmark 2019 & Orthophoto & 2019 & SDFE & 12.5 \\
\hline Geodanmark 2018 & Orthophoto & 2018 & SDFE & 12.5 \\
\hline Geodanmark 2017 & Orthophoto & 2017 & SDFE & 12.5 \\
\hline Geodanmark 2016 & Orthophoto & 2016 & SDFE & 12.5 \\
\hline Geodanmark 2015 & Orthophoto & 2015 & SDFE & 12.5 \\
\hline Denmark's Elevation Model & DEM & 2015 & SDFE & 40 \\
\hline DDOland2014 & Orthophoto & 2014 & SDFE & 12 \\
\hline
\end{tabular}

\subsection{Landslide Mapping}

A detailed description of the method is given in Svennevig et al. (2020a). The nationwide freely available $40 \mathrm{~cm}$ resolution DEM from 2015 is visualized as a multidirectional hillshade model. Landslides are mapped based on their morphological expression in the multidirectional hillshade model when a scarp and a displaced unit are observed (Fig. 2). Mapped landslides are classified into coastal ( $<300 \mathrm{~m}$ to the coast) or inland (>300 $\mathrm{m}$ from the coast) landslides and categorized by their type of movement (fall, slide, flow spread) following the classification from Hungr et al. (2014). Several $12.5 \mathrm{~cm}$ resolution orthophotos annually from 2014-2019 are supporting the investigation (Table 1). The method applied here is similar to Svennevig (2019) and simplified from Slaughter et al. (2017) and Burns \& Madin (2009).

\subsection{Quality control}

Two experts mapped landslides in about half of Denmark each. After completion of the initial mapping, a verification of the mapped polygons was performed by the other expert. Afterwards, an additional validation of the landslide inventory created 
by the two experts was performed by having a third expert mapping landslides in various randomly selected subsample areas to evaluate the completeness of the inventory and to estimate the bias of the mapping first two experts. To achieve this, the area of investigation was subdivided into 658 tiles with a size of $10 \times 10 \mathrm{~km}$. Out of the 658 tiles 192 tiles were randomly selected, creating a subsample with a confidence level of $90 \%$ and an error of $5 \%$ (Fig. 3).

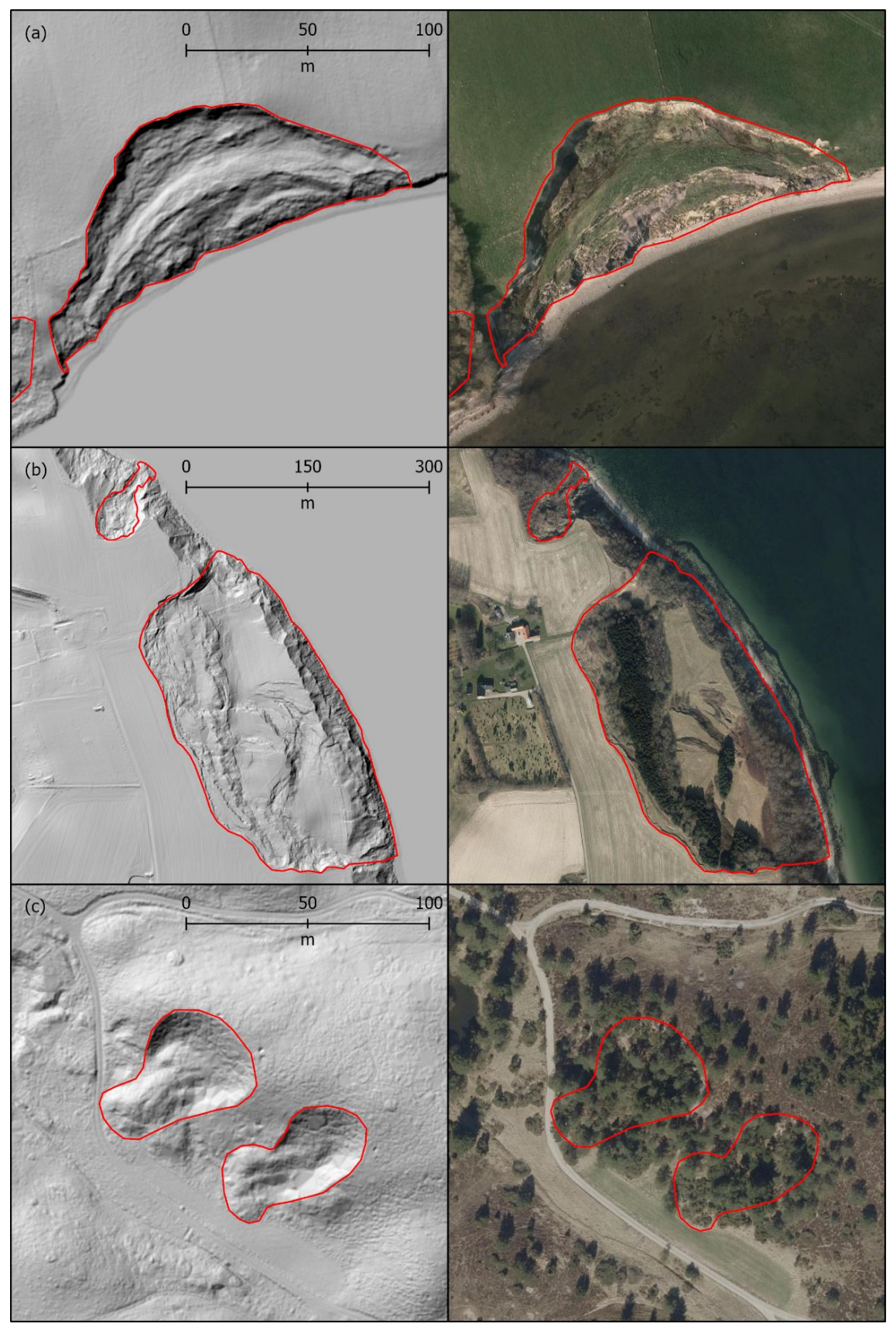

Figure 2. Examples of mapped landslide polygons in the hillshade model (left) and Orthophoto from 2015 (right) (Geodatastyrelsen, 2015a, b). Shallow coastal slide (a), coastal flow and deep-seated slide partly obscured by agricultural land use (b) and two shallow inland slides visible in the hillshade model but covered by vegetation in the Orthophoto (c). 


\section{The landslide inventory}

The landslide inventory consists of 3202 unique polygons of mapped landslides. The count of types of movement and the number of coastal and inland landslides are shown in Table 2. Alongside the polygonal shape, every landslide is associated with a unique identifier. The area $\left(\mathrm{m}^{2}\right)$ and perimeter length $(\mathrm{m})$ of every landslide are provided as well as the $\mathrm{X} \& \mathrm{Y}$ coordinates of the center point. By area, the largest slides comprise $327,001 \mathrm{~m}^{2}$. Landslides were mapped to a minimum area of $25 \mathrm{~m}^{2}$. Analysis of the mapped landslides shows that most landslides in Denmark are shallow rotational slides. However, the database underrepresents processes with undistinguishable morphologies and expressions in the DEM such as rockfalls and mudflows. However, there are only a few areas in Denmark with the geological preconditions facilitating rockfalls. The vast majority of landslides recorded are located in landscapes covered in glacial till. Although all mapped landslides must have occurred after the last glaciation, as their morphological expression would have been erased by the activity of the ice sheet, there is no data available in the landslide database when individual landslides emerged. Landscapes that were not covered by ice during the LGM are almost entirely absent of landslides today (Fig. 1).

Table 2. Landslide types of movement and setting

\begin{tabular}{llll}
\hline Type of Movement & Coast & Inland & Total \\
\hline Fall & 62 & 0 & 62 \\
\hline Slides & 2488 & 335 & 2823 \\
\hline Spreads & 1 & 115 & 116 \\
\hline Flows & 155 & 46 & 201 \\
\hline Total & $\mathbf{2 7 0 6}$ & $\mathbf{4 9 6}$ & $\mathbf{3 2 0 2}$
\end{tabular}

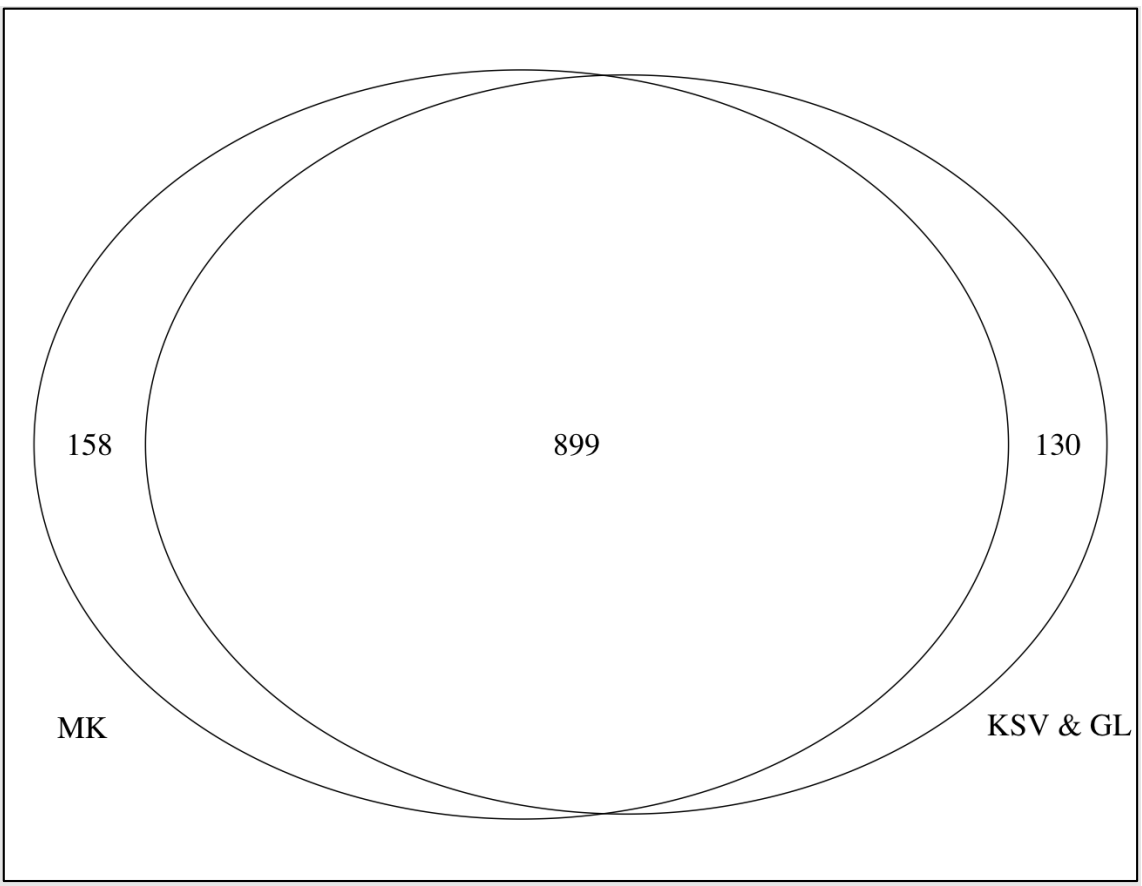

Figure 3. Venn diagram with the number of mapped landsides in the randomly selected tiles by the two initial experts and the quality control (MK, KSV \& GL: 899), the number of landslides only mapped by the quality control (MK: 158) and the number of landslides 
In most cases, the mapped landslides record single events with process durations that span from an instantaneous event to several decades or even centuries and thus some are still active while others are inactive landforms today. Therefore, the present landslide inventory only represents a snapshot of the landslide activity in Denmark at the time of recording from the 2015 DEM. However, the landslide inventory does not contain any information about current or past activity or inactivity. In some cases, landslide areas overlap each other making it more difficult to distinguish individual landslide morphologies. Without dating every single landslide, a further distinction is not possible in these cases. Land use such as farming and infrastructure development may have led to an underrepresentation of landslides in these areas due to intensive cultivation and site development, especially in the inland areas. Nevertheless, around $85 \%$ of the mapped landslides are in coastal environments, often on a cliff at the edge of agriculturally used land. Farmers usually avoid those steep slopes with their heavy and expensive equipment. In some areas along the coastal cliffs, abandoned quarries show morphological expressions similar to landslides in the DEM. The absence of landslide deposits can be the only distinction between the morphological expression of a coastal quarry and a landslide in the DEM. Occasionally quarries may have been mistakenly mapped as landslides during the mapping. In some cases, landslides evolved on the steep slopes of a quarry, sliding into the former pit and in other cases, quarry activity may have overprinted landslides.

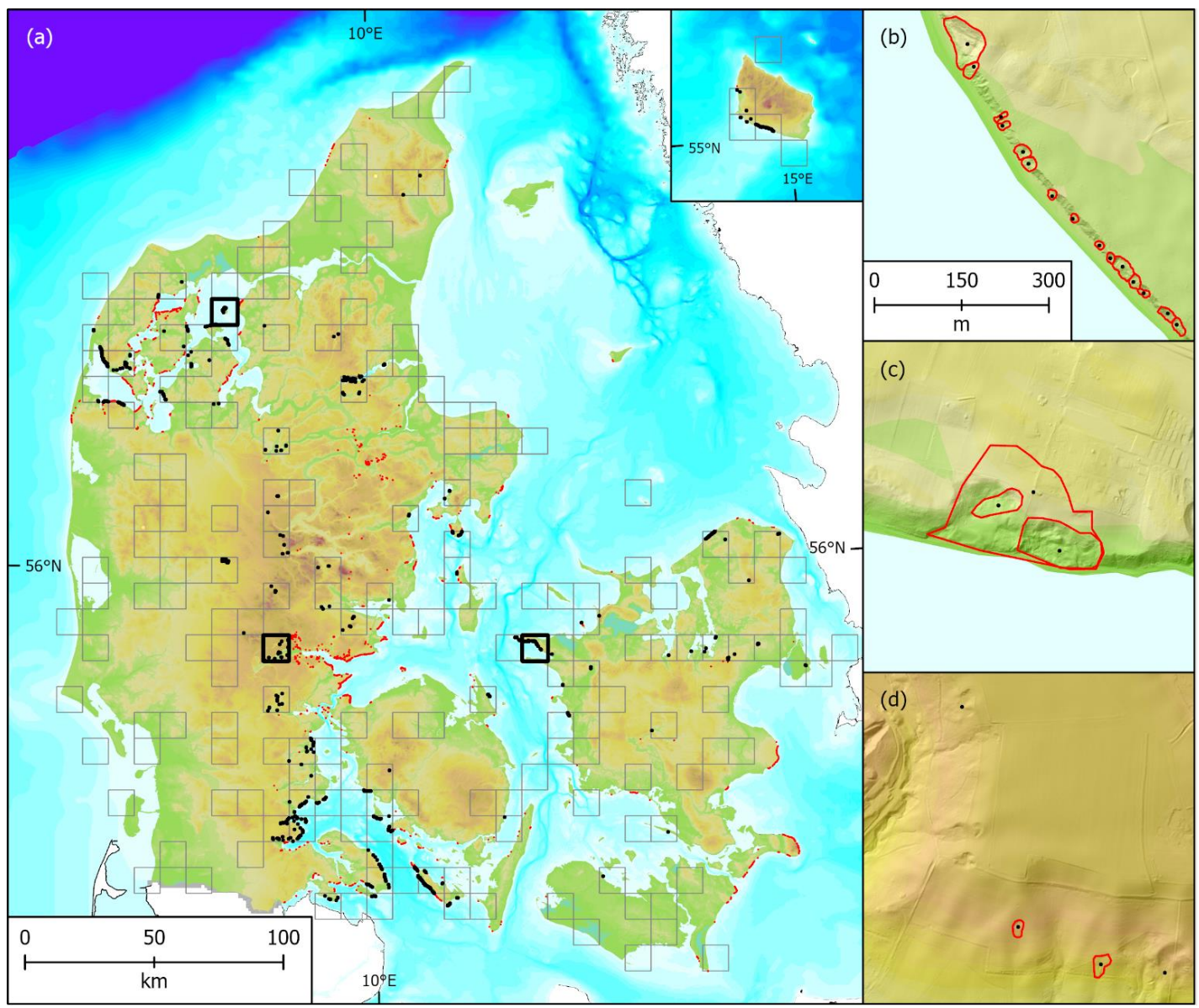

Figure 4. Landslide inventory quality control with 192 randomly selected tiles across Denmark. Black dots show the 1057 landslides mapped by the third mapper (a), sequence of mapped landslide polygons along the coast with a high accordance of quality control points (b), nested landslides with quality control points for each polygon (c) and mapped inland landslides with quality control points that show additional landslides that were missed by the initial mappers (d). 
Within the area of the subsample plots for quality control, the two experts had initially mapped 1029 landslides and the quality control mapped 1057 landslides, a difference of 2.7\%. However, 899 of those landslides were identical, 130 landslides were only mapped during the initial mapping and 158 only during the quality control (Fig. 3). Provided that the combined landslide mapping effort of the initial investigation and the quality control detected the true number of landslides (1187), the initial effort discovered $87 \%$ and the quality control 89\% of all landslides. Furthermore, $142(4.2 \%)$ landslides in the entire study area were validated by visiting the landslides in the field or by mentions in other resources such as previous publications or newspaper articles.

Based on the careful observation of the entire study area and the implemented quality control, the landslide inventory can be considered $87 \%$ complete with a confidence level of $90 \%$ and an error of 5\% for the 2015 DEM. However, a few landslides always remain undetected and new landslides will have emerged since the DEM was recorded. According to the landslide inventory protocol from Burns \& Madin (2009) we only mapped landslides with a moderate to high confidence. The high confidence level in combination with the high quality of the input datasets, lets us conclude that all landslides included in the database are actually landslides.

\section{Data availability}

The landslide dataset and a document with metadata are freely available from https://doi.org/10.6084/m9.figshare.16965439.v1 (Svennevig and Luetzenburg, 2021) and can also be viewed through a web map environment (https://data.geus.dk/landskred/) where layers such as the hillshade model, soil map, Pre-Quaternary geology, etc. can be displayed for context. The landslide dataset is provided in the form of an Environmental Systems Research coastal or inland and movement type. The definitions of each attribute are provided in an additional metadata text document. The DEM is available for download in $10 \mathrm{~km}$ tiles (https://download.kortforsyningen.dk/content/dhmterræn-04-m-grid).

\section{Significance of the dataset}

The motivation for creating and freely providing this landslide inventory is twofold:

1. The first national landslide inventory for Denmark is an important step towards a more comprehensive hazard and risk framework for Denmark. The inventory enables local, regional and national stakeholders to implement landslides into their risk reduction strategies. Furthermore, a legislative framework implementing landslide risk and damage may build upon this dataset. With the expected increase in global landslide activities due to climate change, a landslide risk reduction strategy is now more important than ever before (Gariano and Guzzetti, 2016). In Denmark, a combination of increases in frequency and magnitude of heavy precipitation events, ground water level rises, storm surges and a general increase in relative sea level make a higher landslide activity in the future very likely. Therefore, it is crucial to better understand the underlying processes causing landslides and develop effective risk reduction strategies to protect human lives and property.

2. Providing an expert based high quality, scientifically evaluated landslide inventory to the machine and deep learning research community. The landslide data set is validated and extends the availability of urgently needed training datasets for automated mapping methods. The consistently high amount of time required to manually compile landslide inventories stands in contrast to the increase in data available for landslide mapping. Future challenges in landslide inventory mapping lie in developing methods to reliably automate the process. The present dataset provides a valuable resource to train and develop future 
230 algorithms for this task. Additionally, this is one of the few landslide inventories providing a statistical error estimation of the completeness of the number of mapped landslides.

\section{Author contribution}

KSV: conceptualization. GL \& KSV: data curation, formal analysis, visualization \& writing original draft. MK: quality control. All: discussion of dataset, review \& editing.

\section{Acknowledgements}

GL has received funding from the European Union's Horizon 2020 research and innovation program under the Marie Skłodowska-Curie grant agreement No 801199.

\section{Competing interests}

The authors declare that they have no conflict of interest.

\section{References}

Alberti, S., Senogles, A., Kingen, K., Booth, A., Castro, P., DeKoekkoek, J., Glover-Cutter, K., Mohney, C., Olsen, M., and Leshchinsky, B.: The Hooskanaden Landslide: historic and recent surge behavior of an active earthflow on the Oregon Coast, Landslides, 17, 2589-2602, https://doi.org/10.1007/s10346-020-01466-8, 2020.

Brardinoni, F., Slaymakerl, O., and Hassan, M. A.: Landslide inventory in a rugged forested watershed: a comparison

245 between air-photo and field survey data, Geomorphology, 54, 179-196, https://doi.org/10.1016/S0169-555X(02)00355-0., 2003.

Burns, W. J. and Madin, I. P.: Protocol for Inventroy Mapping of Landslide Deposits from Light Detection and Ranging (LiDAR) Imagery, Oregon Department of Geology and Mineral Industries, 2009.

Busby, J. P., Gourry, J. C., Senfaute, G., Pedersen, S. A. S., and Mortimore, R.: Can we predict coastal cliff failure with

250 remote, indirect measurements?, in: Instability, planning and management, edited by: Jakeways, J., and McInnes, R., Thomas Telford, London, 203-208, https://doi.org/10.1680/ipamssstgmp.31326, 2002.

Cavalli, M. and Marchi, L.: Characterisation of the surface morphology of an alpine alluvial fan using airborne LiDAR, Nat Hazard Earth Sys, 8, 323-333, https://doi.org/10.5194/nhess-8-323-2008, 2008.

Chang, K. T., Merghadi, A., Yunus, A. P., Pham, B. T., and Dou, J.: Evaluating scale effects of topographic variables in

255 landslide susceptibility models using GIS-based machine learning techniques, Sci Rep, 9, 12296, https://doi.org/10.1038/s41598-019-48773-2, 2019.

Coe, J. A.: Bellwether sites for evaluating changes in landslide frequency and magnitude in cryospheric mountainous terrain: a call for systematic, long-term observations to decipher the impact of climate change, Landslides, 17, 2483-2501, https://doi.org/10.1007/s10346-020-01462-y, 2020.

260 Colombo, A., Lanteri, L., Ramasco, M., and Troisi, C.: Systematic GIS-based landslide inventory as the first step for effective landslide-hazard management, Landslides, 2, 291-301, https://doi.org/10.1007/s10346-005-0025-9, 2005.

Crosby, C. J.: Lidar and Google Earth: Simplifying access to high-resolution topography data, in: Google Earth and Virtual Visualizations in Geoscience Education and Research, https://doi.org/10.1130/2012.2492(03), 2012.

Cruden, D. M. and Varnes, D. J.: Landslide Types and Processes, Transportation Research Board, 36-75, 1996.

265 Damm, B. and Klose, M.: The landslide database for Germany: Closing the gap at national level, Geomorphology, 249, 8293, http://dx.doi.org/10.1016/j.geomorph.2015.03.021, 2015.

Denmark, S.: Denmark in Figures, Statistics Denmark, 2019.

EEA: European Digital Elevation Model (EU-DEM), version 1.1, 2016.

Fiorucci, F., Cardinali, M., Carla, R., Rossi, M., Mondini, A. C., Santurri, L., Ardizzone, F., and Guzzetti, F.: Seasonal

270 landslide mapping and estimation of landslide mobilization rates using aerial and satellite images, Geomorphology, 129, 5970, https://doi.org/10.1016/j.geomorph.2011.01.013, 2011.

Froude, M. J. and Petley, D. N.: Global fatal landslide occurrence from 2004 to 2016, Nat Hazard Earth Sys, 18, 2161-2181, https://doi.org/10.5194/nhess-18-2161-2018, 2018.

Galli, M., Ardizzone, F., Cardinali, M., Guzzetti, F., and Reichenbach, P.: Comparing landslide inventory maps,

Geomorphology, 94, 268-289, https://doi.org/10.1016/j.geomorph.2006.09.023, 2008. 
Gariano, S. L. and Guzzetti, F.: Landslides in a changing climate, Earth-Sci Rev, 162, 227-252,

http://dx.doi.org/10.1016/j.earscirev.2016.08.011, 2016.

Geodatastyrelsen: Geodanmark $201512.5 \mathrm{~cm}$, Styrelsen for Dataforsyning og Effektivisering, WMS Service, $2015 \mathrm{a}$.

Geodatastyrelsen: Denmark's Elevation Model, Styrelsen for Dataforsyning og Effektivisering, WMS Service, $2015 \mathrm{~b}$.

280 Guzzetti, F., Mondini, A. C., Cardinali, M., Fiorucci, F., Santangelo, M., and Chang, K.-T.: Landslide inventory maps: New tools for an old problem, Earth-Sci Rev, 112, 42-66, https://doi.org/10.1016/j.earscirev.2012.02.001, 2012.

Hao, L. N., Rajaneesh, A., van Westen, C., Sajinkumar, K. S., Martha, T. R., Jaiswal, P., and McAdoo, B. G.: Constructing a complete landslide inventory dataset for the 2018 monsoon disaster in Kerala, India, for land use change analysis, Earth System Science Data, 12, 2899-2918, https://doi.org/10.5194/essd-12-2899-2020, 2020.

285 Herrera, G., Mateos, R. M., García-Davalillo, J. C., Grandjean, G., Poyiadji, E., Maftei, R., Filipciuc, T.-C., Jemec Auflič, M., Jež, J., Podolszki, L., Trigila, A., Iadanza, C., Raetzo, H., Kociu, A., Przyłucka, M., Kułak, M., Sheehy, M., Pellicer, X. M., McKeown, C., Ryan, G., Kopačková, V., Frei, M., Kuhn, D., Hermanns, R. L., Koulermou, N., Smith, C. A., Engdahl, M., Buxó, P., Gonzalez, M., Dashwood, C., Reeves, H., Cigna, F., Liščák, P., Pauditš, P., Mikulènas, V., Demir, V., Raha, M., Quental, L., Sandić, C., Fusi, B., and Jensen, O. A.: Landslide databases in the Geological Surveys of Europe,

290 Landslides, 15, 359-379, https://doi.org/10.1007/s10346-017-0902-z, 2017.

Highland, L. M. and Bobrowsky, P.: The Landslide Handbook - A Guide to Understanding Landslides, in, USGS, 2008.

Houmark-Nielsen, M.: A lithostratigraphy of Weichselian glacial and interstadial deposits in Denmark, Bulletin of the Geological Society of Denmark, 46, 101-114, https://doi.org/10.37570/bgsd-1999-46-09, 1999.

Houmark-Nielsen, M.: Pleistocene Glaciations in Denmark: A Closer Look at Chronology, Ice Dynamics and Landforms, in:

295 Quaternary Glaciations - Extent and Chronology - A Closer Look, Developments in Quaternary Sciences, 47-58, https://doi.org/10.1016/B978-0-444-53447-7.00005-2, 2011.

Hungr, O., Leroueil, S., and Picarelli, L.: The Varnes classification of landslide types, an update, Landslides, 11, 167-194, https://doi.org/10.1007/s10346-013-0436-y, 2014.

Hutchinson, J. N.: Chalk flows from the coastal cliffs of northwest Europe, in: Catastrophic landslides: Effects, occurrence,

300 and mechanisms, edited by: Evans, S. G., and DeGraff, J. V., Geological Society of America Reviews in Engineering Geology, Boulder, Colorado, 257-302, 2002.

Kabuth, A. K. and Kroon, A.: Wave energy fluxes and multidecadal shoreline changes in two coastal embayments in Denmark, Ocean Dynam, 64, 741-754, https://doi.org/10.1007/s10236-014-0709-6, 2014.

Kabuth, A. K., Kroon, A., and Pedersen, J. B. T.: Multidecadal Shoreline Changes in Denmark, J Coastal Res, 30, 714-728,

305 https://doi.org/10.2112/JCOASTRES-D-13-00139.1, 2013.

Kakavas, M. P. and Nikolakopoulos, K. G.: Digital Elevation Models of Rockfalls and Landslides: A Review and MetaAnalysis, Geosciences, 11, https://doi.org/10.3390/geosciences11060256, 2021.

Kirschbaum, D. B., Adler, R., Hong, Y., Hill, S., and Lerner-Lam, A.: A global landslide catalog for hazard applications: method, results, and limitations, Natural Hazards, 52, 561-575, https://doi.org/10.1007/s11069-009-9401-4, 2009.

310 Lissak, C., Bartsch, A., De Michele, M., Gomez, C., Maquaire, O., Raucoules, D., and Roulland, T.: Remote Sensing for Assessing Landslides and Associated Hazards, Surv Geophys, 41, 1391-1435, https://doi.org/10.1007/s10712-020-09609-1, 2020.

Ludwig, K. A., Ramsey, D. W., Wood, N. J., Pennaz, A. B., Godt, J. W., Plant, N. G., Luco, N., Koenig, T. A., Hudnut, K. W., Davis, D. K., and Bright, P. R.: Science for a risky world-A U.S. Geological Survey plan for risk research and

315 applications, Reston, VA, Report 1444, https://doi.org/10.3133/cir1444, 2018.

Malamud, B. D., Turcotte, D. L., Guzzetti, F., and Reichenbach, P.: Landslide inventories and their statistical properties, Earth Surface Processes and Landforms, 29, 687-711, https://doi.org/10.1002/esp.1064, 2004.

Mäntyniemi, P., Sørensen, M. B., and Tatevossian, R. E.: Testing the Environmental Seismic Intensity Scale on Data Derived from the Earthquakes of 1626, 1759, 1819, and 1904 in Fennoscandia, Northern Europe, Geosciences, 11,

320 https://doi.org/10.3390/geosciences11010014, 2020.

Mateos, R. M., Lopez-Vinielles, J., Poyiadji, E., Tsagkas, D., Sheehy, M., Hadjicharalambous, K., Liscak, P., Podolski, L., Laskowicz, I., Iadanza, C., Gauert, C., Todorovic, S., Auflic, M. J., Maftei, R., Hermanns, R. L., Kociu, A., Sandic, C., Mauter, R., Sarro, R., Bejar, M., and Herrera, G.: Integration of landslide hazard into urban planning across Europe, Landscape and Urban Planning, 196, https://doi.org/10.1016/j.landurbplan.2019.103740, 2020.

325 Moon, S., Shelef, E., and Hilley, G. E.: Recent topographic evolution and erosion of the deglaciated Washington Cascades inferred from a stochastic landscape evolution model, J Geophys Res-Earth, 120, 856-876, https://doi.org/10.1002/2014JF003387, 2015.

Morgan, A. J., Chao, D., Froese, C. R., Martin, C. D., and Kim, T. H.: LiDAR based landslide inventory and spatial analysis, Peace River, Alberta, 2011.

330 Nadim, F., Pedersen, S. A. S., Schmidt-Thome, P., Sigmundsson, F., and Engdahls, M.: Natural hazards in Nordic countries, Episodes, 31, 176-184, https://doi.org/10.18814/epiiugs/2008/v31i1/024, 2008.

Palma, A., Garrill, R., Brook, M. S., Richards, N., and Tunnicliffe, J.: Reactivation of coastal landsliding at Sunkist Bay, Auckland, following ex-Tropical Cyclone Debbie, 5 April 2017, Landslides, 17, 2659-2669, https://doi.org/10.1007/s10346020-01474-8, 2020.

335 Pedersen, S. A. S. and Damholt, T.: Cliff collapse at Stevns Klint, south-east Denmark, Geological Survey of Denmark and Greenland Bulletin, 26, 33-36, https://doi.org/10.34194/geusb.v26.4745, 2012.

Pedersen, S. A. S. and Gravesen, P.: Structural development of Maglevandsfald: a key to understanding the glaciotectonic architecture of Mons Klint, SE Denmark, Geological Survey of Denmark and Greenland Bulletin, 17, 29-32, https://doi.org/10.34194/geusb.v17.5007, 2009. 
340 Pedersen, S. A. S. and Møller, I.: Prediction and risk evaluation of chalk cliff collapse: the PROTECT project, Geological Survey of Denmark and Greenland (GEUS) Bulletin, 4, 89-92, https://doi.org/10.34194/geusb.v4.4793 2004.

Pedersen, S. A. S., Foged, N., and Frederiksen, J.: Extent and economic significance of landslides in Denmark, Faroe Islands and Greenland, in: Landslides: Extent and Economic Significance, Brabb \& Harrod, Rotterdam, 1989.

Pellicani, R. and Spilotro, G.: Evaluating the quality of landslide inventory maps: comparison between archive and surveyed

345 inventories for the Daunia region (Apulia, Southern Italy), Bulletin of Engineering Geology and the Environment, 74, 357 367, https://doi.org/10.1007/s10064-014-0639-z, 2014.

Prakash, N., Manconi, A., and Loew, S.: Mapping Landslides on EO Data: Performance of Deep Learning Models vs. Traditional Machine Learning Models, Remote Sensing, 12, https://doi.org/10.3390/rs12030346 2020.

Prior, D. B.: Coastal Mudslide Morphology and Processes on Eocene Clays in Denmark, Geogr Tidsskr-Den, 76, 14-33,

350 http://dx.doi.org/10.1080/00167223.1977.10649071, 1977.

Prior, D. B. and Eve, R. M.: Coastal landslide morphology at Røsnæs, Denmark, Geogr Tidsskr-Den, 74, 12-20, http://dx.doi.org/10.1080/00167223.1975.10649043, 1975.

Rosi, A., Tofani, V., Tanteri, L., Tacconi Stefanelli, C., Agostini, A., Catani, F., and Casagli, N.: The new landslide inventory of Tuscany (Italy) updated with PS-InSAR: geomorphological features and landslide distribution, Landslides, 15,

355 5-19, https://doi.org/10.1007/s10346-017-0861-4, 2017.

Santangelo, M., Marchesini, I., Bucci, F., Cardinali, M., Fiorucci, F., and Guzzetti, F.: An approach to reduce mapping errors in the production of landslide inventory maps, Nat Hazard Earth Sys, 15, 2111-2126, https://doi.org/10.5194/nhess-15-2111$\underline{2015}, 2015$.

Schou, A.: Danish Coastal Cliffs in Glacial Deposits, Geografiska Annaler, 31, 357-364, 1949.

360 Shugar, D. H., Jacquemart, M., Shean, D., Bhushan, S., Upadhyay, K., Sattar, A., Schwanghart, W., McBride, S., de Vries, M. V. W., Mergili, M., Emmer, A., Deschamps-Berger, C., McDonnell, M., Bhambri, R., Allen, S., Berthier, E., Carrivick, J. L., Clague, J. J., Dokukin, M., Dunning, S. A., Frey, H., Gascoin, S., Haritashya, U. K., Huggel, C., Kaab, A., Kargel, J. S., Kavanaugh, J. L., Lacroix, P., Petley, D., Rupper, S., Azam, M. F., Cook, S. J., Dimri, A. P., Eriksson, M., Farinotti, D.,

Fiddes, J., Gnyawali, K. R., Harrison, S., Jha, M., Koppes, M., Kumar, A., Leinss, S., Majeed, U., Mal, S., Muhuri, A.,

365 Noetzli, J., Paul, F., Rashid, I., Sain, K., Steiner, J., Ugalde, F., Watson, C. S., and Westoby, M. J.: A massive rock and ice avalanche caused the 2021 disaster at Chamoli, Indian Himalaya, Science, 373, 300-306, https://doi.org/10.1126/science.abh4455, 2021.

Slaughter, S. L., Burns, W. J., Mickelson, K. A., Jacobacci, K. E., Biel, A., and Contreras, T. A.: Protocol for Landslide Inventory Mapping from LiDAR Data in Washington State, Washington Geological Survey Bulletin, 82, 2017.

370 Sorgenfrei, T. and Berthelsen, O.: Geologi Og Vandboring, Danmarks Geologiske Unders $\varnothing$ gelse III, 31, 1954. Svennevig, K.: Preliminary landslide mapping in Greenland, Geological Survey of Denmark and Greenland Bulletin, 43, https://doi.org/10.34194/GEUSB-201943-02-07, 2019.

Svennevig, K. and Keiding, M.: En dansk nomenklatur for landskred, Geologisk Tidsskrift, 19-30, 2020. Svennevig, K. and Luetzenburg, G.: Danish landslide inventory 211104 [dataset],

375 https://doi.org/10.6084/m9.figshare.16965439.v1, 2021.

Svennevig, K., Luetzenburg, G., Keiding, M. K., and Pedersen, S. A. S.: Preliminary landslide mapping in Denmark indicates an underestimated geohazard, Geus Bulletin, 44, https://doi.org/10.34194/geusb.v44.5302, 2020a.

Svennevig, K., Dahl-Jensen, T., Keiding, M., Boncori, J. P. M., Larsen, T. B., Salehi, S., Solgaard, A. M., and Voss, P. H.: Evolution of events before and after the 17 June 2017 rock avalanche at Karrat Fjord, West Greenland - a multidisciplinary

380 approach to detecting and locating unstable rock slopes in a remote Arctic area, Earth Surface Dynamics, 8, 1021-1038, https://doi.org/10.5194/esurf-8-1021-2020, 2020b.

Trigila, A., Iadanza, C., and Spizzichino, D.: Quality assessment of the Italian Landslide Inventory using GIS processing, Landslides, 7, 455-470, https://doi.org/10.1007/s10346-010-0213-0, 2010.

Van Den Eeckhaut, M., Poesen, J., Verstraeten, G., Vanacker, V., Moeyersons, J., Nyssen, J., and van Beek, L. P. H.: The

385 effectiveness of hillshade maps and expert knowledge in mapping old deep-seated landslides, Geomorphology, 67, 351-363, https://doi.org/10.1016/j.geomorph.2004.11.001, 2005.

Zhong, C., Liu, Y., Gao, P., Chen, W. L., Li, H., Hou, Y., Nuremanguli, T., and Ma, H. J.: Landslide mapping with remote sensing: challenges and opportunities, International Journal of Remote Sensing, 41, 1555-1581, https://doi.org/10.1080/01431161.2019.1672904, 2020.

390 Zieher, T., Perzl, F., Rossel, M., Rutzinger, M., Meissl, G., Markart, G., and Geitner, C.: A multi-annual landslide inventory for the assessment of shallow landslide susceptibility - Two test cases in Vorarlberg, Austria, Geomorphology, 259, 40-54, http://dx.doi.org/10.1016/j.geomorph.2016.02.008, 2016. 